臨㕅

\begin{abstract}
左房粘液腫の 2 例
\section{TWO CASES OF LEFT ATRIAL MYXOMA WITH DIFFERENT FINDINGS AND FEATURES}

Hidekatsu Sugrmoto, MD, Teruo SaKaI, MD, Hisashi Kanaya, MD, Yoshitaka Dor, MD Masahide TAKIr, MD and Kikuo Arakawa, MD

The Second Department of Internal Medicine, Fukuoka University, Fukuoka

Koichi Toxunaga, MD

The Department of Cardiac Surgery, Kyushu University, Fukuoka

概要 心䁍腫㵣は希な疾患であるが，われわれは最近半年間に臨床所見の互に異なつた 2 例の左房粘 液腫を経験した。何れる超音波診断法により診断し，短期間に外科的に治癋させ得たので報告する。

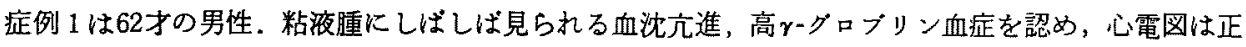
常洞調律で，聴診上では僧帽升狭窄泟同然であり，塞栓症の既往を有していた。摘出標本は柔わらか

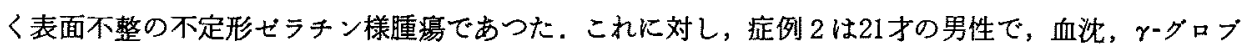
リンともに正常．心電図は心房細動で，聴診上では僧帽弁閉鎖不全症同然であり，塞栓症の合併はな かつた，摘出標本は硬く，球状であり，表面は非常に平滑であつた，2 例共，外来初診時の超音波診 断法によつて，拡張期に僧帽升前尖後方に，異常塊状エコーを認め，収縮期には左房内に㷌納する 状態が認められた。偖つて左房粘庥腫と診断した。，心音図上特徽的な tumor ejection sound と early diastolic sound,を認め，それぞれ心尖拍動図のsystolic upstrokeの切痕抢よびsystolic down strokeの隆 起に一致していた。これらの音の発生源を超音波高速度連続撮影法との対比によつて検討した。
\end{abstract}

異なつた所見と性状を呈した

\section{はじめに}

心蔵腫湯は極めて希な疾患であるが，その殆ど は粘液腫である。これは放置すればいずれ致命的 状態に陥る一万，早期に診断し手術すれば完治可 能である観点から，是非とも早期に発見されなけ

[昭和50年11月23日第151回九州地方会推感]

昭和50年11月23日第151回内科学会九州地方会に て症例 1 を報告した。
ればならない。われわれは最近半年間に 2 例の左 房粘液腫を外来初診時の超音波診断法で診断し， 速かに完治にもつてゆくことが出来たので，若干 の考察を加えて報告する．

\section{症 例}

症例 1 ： 一, 62才, 男性, 農漁業。

主訴: 心悸元進, 起座呼吸, 下腿浮腫.

既往歴： 昭和 20 年広島で原爆に被爆したが, 
とくにそれによる障害は認められない。

家族歴：特記すべきことなし．

現病歴： 昭和47年頃より心㤓九進を自覚し始 めたが放置していた，昭和48年12月一過性意識消 失発作があつた，49年 1 月にも意識消失発作を来 たし，今度は両下肢と右上肢の完全麻痷，扣上び 左眼視力障害をきたしたが失明を残して他はほよ゙ 完全に回復した．昭和 00 年 5 月両下肢，腰背部に 高度な浮腫が笑発し，起座呼吸を伴つた，同年 6 月浮腫は軽快したが起座呼吸が強いため，6月20 日当科外来受診し即日入院となつた。

入院時現症：体格中等度, 栄養可, 脈拍数毎 分88 整, 血圧 $114 / 72 \mathrm{~mm} \mathrm{Hg}$ (右腕, 臥位), 貧血 (一), 黄疸 (一), 左眼光覚なし. 頝静脈怒脹高 度, 肺肝境界第 6 助骨, 肺野全体で湿性ラ音聴 取. 心音は I 音の光進と著明な分裂，心尖部で逆 流性收緶期雑音 (3/6) と比較的高調な拡張期 ンブル音(3/6)を聴取．僧帽弁開放音（一），体位 変換による心音变化 $(-)$, 肝 4 横指触知, 腹水 (一)，下肢に著明な浮腫を認めた，左眼底所見で は乳頭荅白，動脈白線化，視神経萎縮，古い出血
斑と白斑を認めた．右眼底には異常を認めなかつ た。

症例 2 ： 21 才, 男性, 工員.

主訴：夜間呼吸困難 (軽度).

既往歴：特記すべきことなし。

家族歴：特記すべきことなし．

現病歴：昭和48年心臓升膜症と言われたが放 置していた。昭和50年 1 月頃より夜間仰卧位で心 悸六進を自覚し始め，4月頃より1〜2 カ月に一 度程左前胸部をドンと吒かれる感じを覚えるよう になつた，同年 9 月全身倦急感，悪心，呕吐，黄 疸が出現し肝炎の猃断のもとに治療を受けていた が再度心雑音を指摘され，同年11月 4 日当科外来 受診し，入院となる。

入院時現症：体格中等度, 栄養良, 脈拍数毎 分約76, 不整, 血圧 $138 / 78 \mathrm{~mm} \mathrm{Hg}$ (右腕, 臥位), 筫 血(一), 黄疸 (一), 頚静脈怒脹 (一)。肺肝境界第 5 肋間，呼吸音正常，心音は I 音穴進し，心尖部 飞高調な逆流性収縮期雑音 $\left(3^{\circ} / 6\right)$, 拡張早期心音 を主とし，その他僅かに拡張期ランブル音 $(1 \%$ )

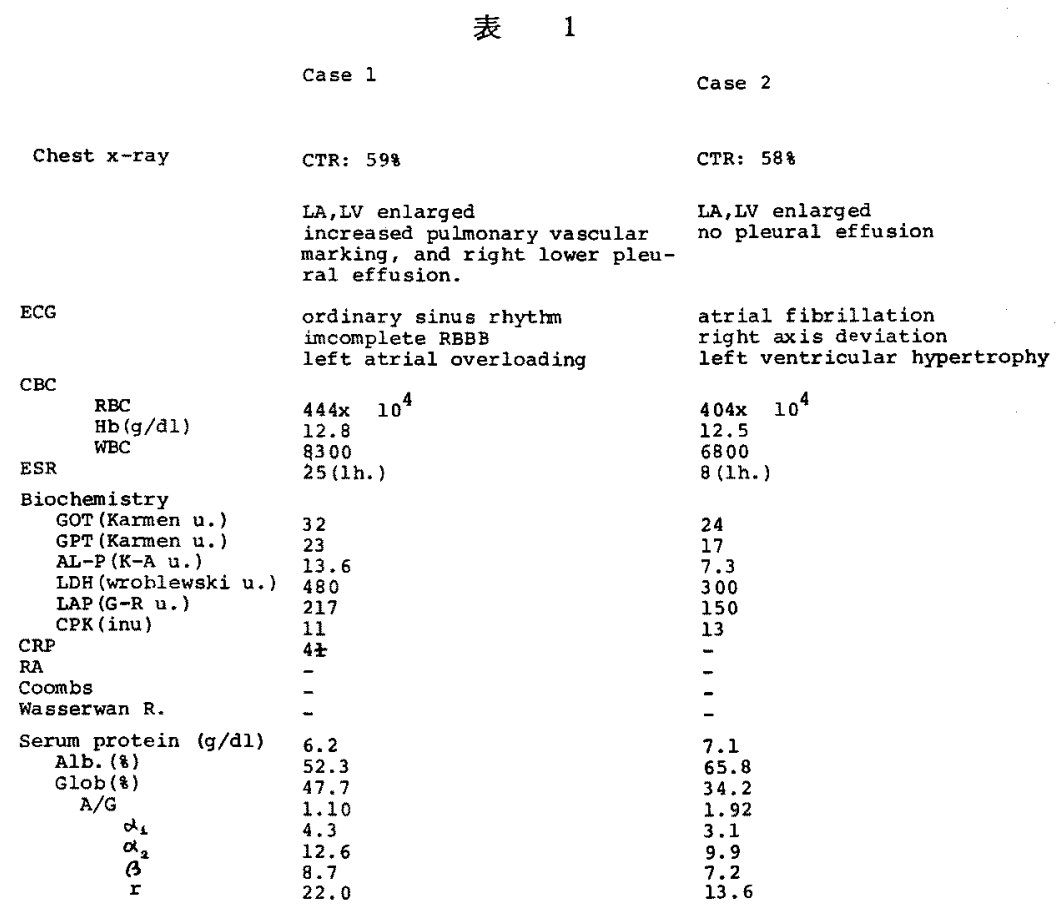


を聴取. 体位変換による心音変化(一), 肝触知し 得ず，浮腫も認められない，眼底正常.

両症例検查成績の比較（表 1)：症例 1 は左 房粘液腫によく見られる血沈六進，血清蛋白分画 の異常を裉めるが, 症例 2 ではそれらは異常値を

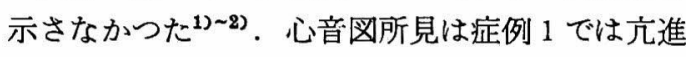
した I 音に続く過剩心音, 全収縮期雑音, 僧帽弁 開放音を伴わない拡張期ランブル音が 記録され た. 症例 2 では I 音の充進, 全収縮期雑音, 拡張 早期心音が記録されている，さらに心尖拍動図で はsystolic upstrokeに切痕があり, down strokeに隆 起を認めた．拡張早期心音はこの隆起に一致して いる. 超音波診断法では 2 例共, 異常塊状エコー

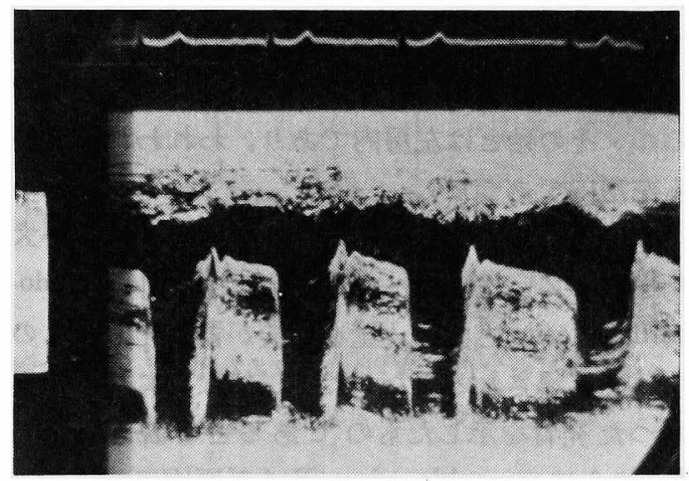

写真 1.Case 2：超音波訩断法 挞張期に僧帽弁 前尖後方に異常エューを認める。

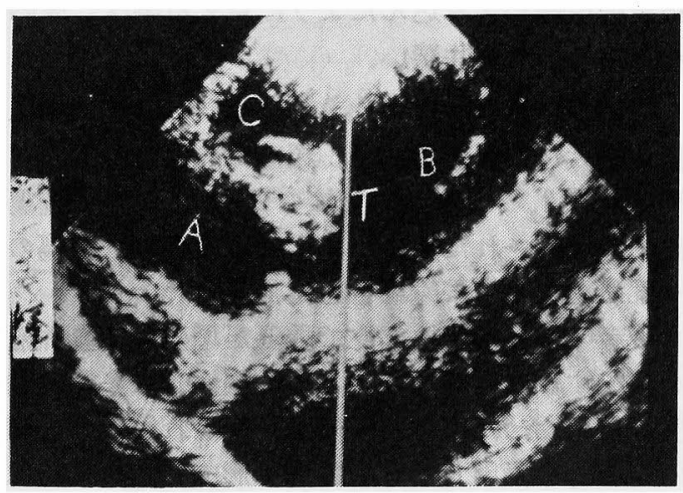

写真 2. Case 2: 超音波断層像 (抾張期). A (左 房), B (左室), C (大動脈起始部), T (腫掦エコ $-)$

昭和 51 年 9 月 10 日
を認め，拡張期には僧帽弁前尖後方に（写真 1 ， 2 )，収縮期には左房内に移動するのが見られた. 症例 2 の 超音波高速度連続撮影法による観察で

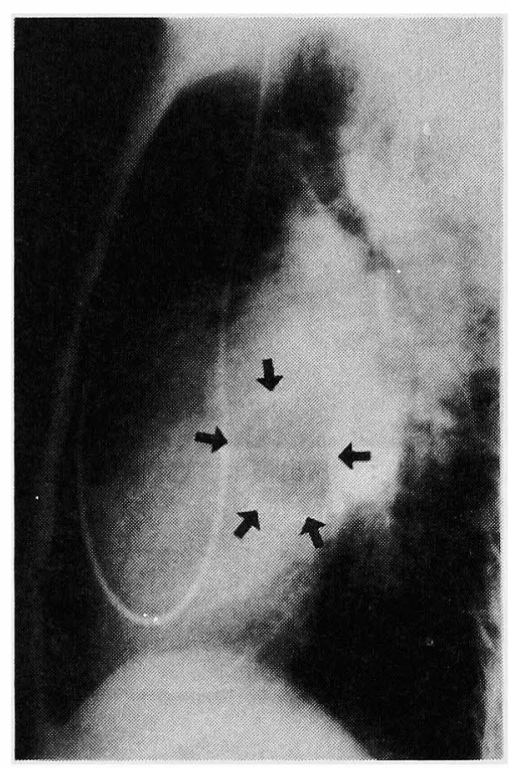

写真 3. Case 2：心血管造影 (収縮期) 左房内に 陰影欠損像を認める。

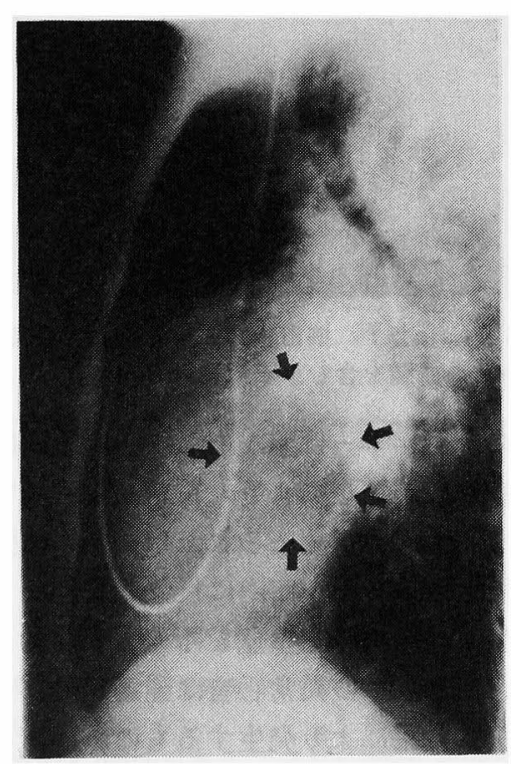

写真 4. Case 2：心血管造影（扗張期）左房と左 室に陰影欠損像を認める。 


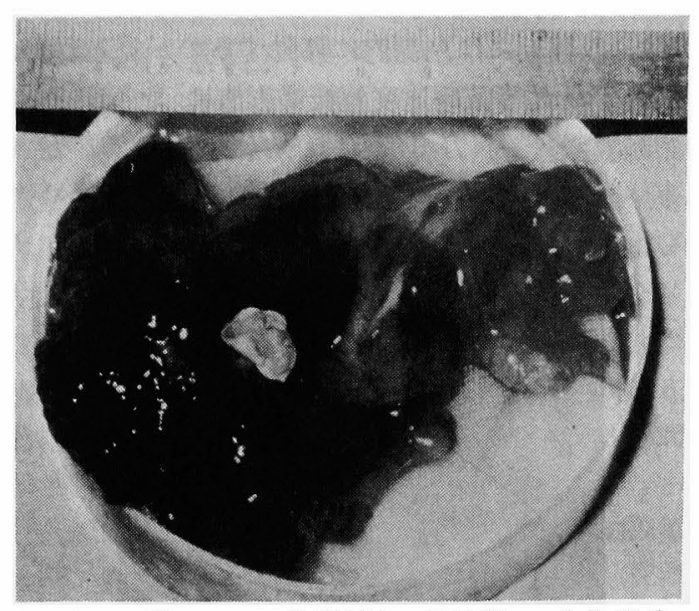

写真 5 . Case 1：摘出檡本 重量 $90 \mathrm{~g}$ ，全体は不 定形ぜラチン様

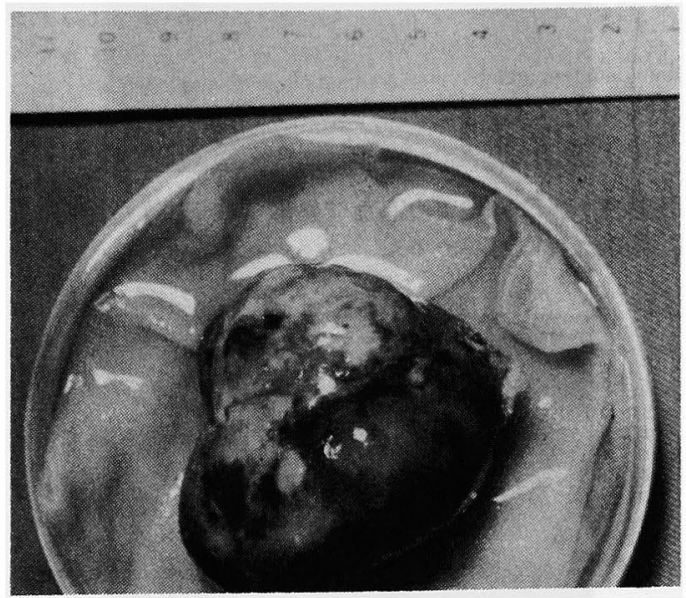

写真 6. Case 2：摘出骠本 重量 $44 \mathrm{~g}$, 硬 2 , 内 部に多数の血腫を含む. 石灰化なし.

は，この塊状ェューは茎を有して心房中隔に付着 し, 左室の収縮拡張により, 左房, 左室間を振子 様運動をすることが認められた。 また，拡張早期 心音は塊状エューが左室内に侵入して伸びきつた 時に発生し，同時に左室壁を吒くような動きも見 られた．従つてこの異常心音は腫瘍が伸びきつた ための張弦効果により発生するものか，あるいは 壁を吅くために起こるものと考えられた，心血管 造影所見は写真 $3 ， 4$ 亿示す. 腫瘍による陰影欠
損像は超音波診断法の所見とよく一致し，収縮期 では左房内にのみ存在し, 拡張期には左室内まで 及んでいる。

2 例共, 左房粘液腫の診断のもとに, その摘出 術が行なわれた，両者の腫瘍の性状は著しく異な つていた，症例 1 は $11 \times 5 \times 3 \mathrm{~cm}(90 \mathrm{~g})$ のゼ チン様の軟かい粘液腫で $1.5 \mathrm{~cm}$ の茎を有し, 卵円 孔付近から発生していた，腫瘍表面および左房壁 内に血栓を認めなかつた。症例 2 は $5 \times 5 \times 3 \mathrm{~cm}$

(44 g) で表面は平滑で硬い球状の粘液腫であ り, 内部に各段階の血腫や出血巣が多数存在して いた。これも同じく卵円孔付近から茎を持つて発 生していて表面には血栓の付着はなからた．摘出 標本は写真 $5 ， 6$ に示している.

\section{考案}

心臓内粘液腫はこれまで 400 例近くの報告があ るが，その殆どは左房内であり，われわれの 2 例 も左房内であつた。

本疾患の原因としては真性の腫瘍とする説が大 勢を占めているが，一方粘液腫はpapillary endocardial lesionと共に, 壁在血栓が器質化したもの で，ただ曝される異なつた機械的な力に対して異 なつた発育を示したものであるとの説もある゙ 6).さらにcoxsackie virus B 4 が原因に関係して いるとする説もある7.ここに示した 2 症例のよ らに, 一方は全く真性腫瘍様に見え，他は血腫を 粘液腫組織が包み込んだよらに見える事は，原因 を考える上で興味深い。

症例 1 に見られたような塞栓症は，心缄内粘液 腫の重大な合併症であり，頻度は45\%に及ぶほど

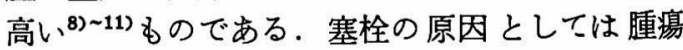
表面に形成された血栓がはずれる場合と，腫瘍の 一部がちぎれて飛ぶ場合とがある。

後者の場合は塞栓部位で腫瘍が増殖し, 動脈瘤 を形成することがあり，とくに脳血管に多発性動 脈瘤を来たせば不幸な転帰る予想され得る。心蔵 内の腫瘍を摘出しても動脈瘤を形成している時は そこで増殖し続ける事がある。

ただ粘液腫摘出によつて, 眼底の白斑が消失し た事から粘液腫は眼底では増殖できないとの報告 
もある ${ }^{(1)}$. 症例 1 は脳血管造影を行なつてはいな いが，多発性脳塞栓，あるいは動脈瘤を形成して いることが充分予想される.

粘液腫の検查所見として血沈六進, 血清蛋白分 画の異常などが特徵的であり 1) 4)，摘出によつて 正常化するとされているが，吻論必発ではなくわ れわれの経験でも一方にしかみられなかつた。

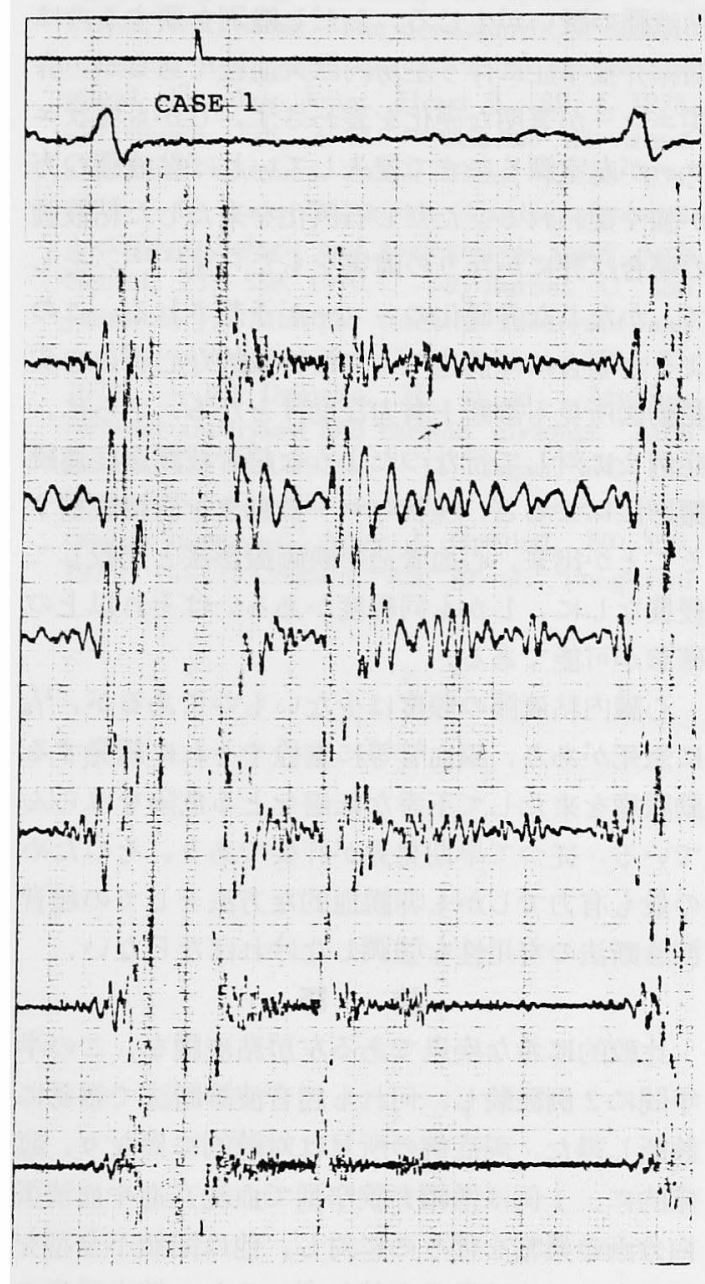

ただ，血沈の亢進は粘液腫の大きさと関連し，再 発により再び異常を示すようになるとの主張もあ るため注意は必要であろら，血清蛋白分画の異 常，とくに $\gamma$-globulinの上昇は粘液腫から放出さ れるpolysaccharideに対する抗体である 可能性が 示唆されている810).

左房粘液腫はその血行動態の類似していること

図 1 。音図

Case 1 は心尖部で記録したものであり，I 音に連続して強勢な数個の心音 (tumor ejection sound) と 収縮期雑音，さらに拡張期ランブル音がある．ＯSは伴っていない。

Case 2 は 4 L S B の心音と心尖拍動図を示した。 systolic upstrokeknotchがり，さらにdown stroke にhump (矢印) が記録されている。それぞれに一致してtumor ejection sound, tumor plop soundを 認める. 
から，しばしば僧帽并膜症と誤断される。聴診上 僧帽升狭窄症や間鎖不全症のいずれの形もとりう るが，鑑別点として心電図は正常洞調律の事が多 く，また体位によつて心雑音が変化することが重 要視されている。われわれの症例にもみられるよ ら火，これらの特徵がない場合ももり診断の決め 手にはならない，しかし，心音図，心尖拍動图を 注意してよぬば，かなり特改的な所見が得られ $3^{2) \sim 7)}$.

心音の特徵の一つは，まず，I音の艺進である が，これは心室の等容収縮期に打ける房一室間圧 較差が大きいことによるといわれている．第 2 に I 音の幅広い分裂あるいはI 音に続く振動音とし て德取される音がある。これは腫瘍が左室から左 仿へと押し戻される時に発生する。心尖拍動図上 systolic upstrokeの切狼として記録される（図1 参). tumor ejection soundといわれ，I 音の前に 聴取される事もある、第 3 亿僧帽手開放音ときわ めて類似した拡張早期心音が聴取されるが，発生. 源としては，腫㕫の左房から左室への侵入が考え られる。心尖拍動図上systolic down strokeに隆起 曲線として認められる。われわれはこの心音の発 生時期を超音波高速度連続撮影法により確認し得 た、腫演の茎が伸びきつた時期に，腫汪塊が左室 壁を吒く動きが見られたため，镸弦効果によるも のか，打音が発生源なのかの判定は出来なかつた が，むしろその両者であるかもしれない，第4は 僧帽弁閉鎖不全による全収縮期雑音の存在であ る。音の性質は症例により異なり，われわれの症 例 2 では寸き間風様の非常に高調な雑音として聴 かれた，第 5 に拡張期ランブル音，第 6 に全体的 な特改として体位変換による心音の変化がある。 以上のような心音も腫瘍性状によりさまざまであ り, 症例 1 と2では異なつた心音を呈していた。 両者共に体位変換による心音変動はなかつたが， 症例 1 は日時により変化していた。

以上のよらな特徵的な所見があるもかかわら ず，聴診上は僧帽升膜症にあまりにも類似してい ることと，極めて希な疾患であることから，外来
では升膜症と診断される事が多い。しかし，近年 急速に普及した超音波診断法は，手軽でしかる粘 液腫の診断に対して極めて有力な手段となる2217) ${ }^{200}$. われわれの症例も2 例共, 外来初診時に僧帽 弁疾患のルーチン検查として超音波診断法を施行 し，左房粘液腫を診断し得た。払張期に僧帽升前 尖後方に異常塊状エコーを認め，収縮期に左房内 にそのェコーが移動する所見が得られれば，左房 粘液腫の疑いが生じる．ただし璼別を要寸るのは 僧帽弁狭窄症に伴う左房内巨大血栓であるが，弁 尖エコーが著明な硬化を表わさず，しかも塊状エ コーが左室深くにまで侵入していれば粘液腫の力 が強く疑われる．たたし石灰化を来たした粘液腫

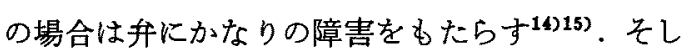
て，かなりな弁硬化のエコーが予想される。この 上らな場合には前述のような特徵的な心音，心尖 拍動図所見も診断上有力な助けとなる。さらに， 症例 2 に対して行なつたような超音波高速度連続 撮影法によると，塊状エコーの動きを直接観察す ることが出来，心血管造影映画撮影法と比較して 侵襲なしに，しかも同程度かあるいはそれ以上の 確䛦が可能である.

心臓内粘液腫の頻度は少ないものであるが，1/8 に急死があり，脳血管等に塞栓やそれに続発する 動脈瘤を来たして不幸な転帰をとる危険をはらん でいる、従つて早期発見が肝要であり，そのため の最も有力でしかも非観血的な方法としての超音 波診断法の有用性を強調しなければならない。

\section{䊅 語}

比較的に希な疾患である左厉粘波腫を，この半 年間に 2 例経験し，何机も超音波診断法で容易に 診断し得た，両症例の所見は対蹠的に異なり，臨 床的に，1 例は僧帽弁狭佂型で血沈六進や血清蛋 白分画の異常を伴うのに対し，他は閉鎖不全型を 呈し，かつ血液異常を伴わず，また，摘出腫痬の 性状も両者非常に異なつていた。

\section{文献}

1) Nasser, WK, et al: Atrial myxoma. I. Clinical and pathologic features in nine cases. Amer 
Heart J 83: 694, 1972 . - 2) Sung, RJ, et al: Hemodynamic features of prolapsing and nonprolapsing left atrial myxoma. Circulation, $51: 342$, 1975. - 3) Jugdutt, BI, et al: An unusual case of recurrent left atrial myxoma. Canadian Med Assoc J, 112: 1099, 1975. -4) Fisher, ER and Hellstrom, HR: Evidence in favor of the neoplastic nature of cardiac myxoma. Amer Heart J, 60: 630, 1960 . -5) Symbas, PN, et al: Experimental left atrial thrombus and atrial myxoma. J Surg Research, 12: 8, 1972. -6) Salyer, WR, et al: The development of cardiac myxomas and papillary endcardial lesions from mural thrombus. Amer Heart J, 89: 4, 1975. -7) Burch, GE, et al: Coxsackie B4 virusea and atrial myxoma. Amer Heart J, 88: 634, 1974. - 8) Price, DL, et al: Cardiac myxoma. A clinicopathologic and angiographic study. Arch Neurol, 23: 558, 1970. -9) Burton, $\mathrm{C}$ and Johnston, J: Multiple cerebral aneurysms and cardiac myxoma. New Engl J Med, 282: 35, 1970. -10) Damasio, H, et al: Multiple cerebral aneurysms and cardiac myxoma. Arch Neurol, 32: 269, 1975. -11) Cogan, DG and Wray-SH: Vascular occlusions in the eye from cardiac myxomas. Amer J Ophthal, 80: 396, 1975. -12) Croxson, RS, et al: Long-term follow-up of atrial myxoma. Brit Heart J, 34: 1018, 1972. -13) Pitt, A, et al: Myxoma of the left atrial hemodynamic and phonocardiographic consequences of sudden tumor movement. Circulation, 36: 408, 1967. - 14) Penny, JL, et al: Calcified left atrial myxoma. Simulating mitral insufficiency. Circulation 36: 417, 1967. -15) Martin, CE, et al: Calcified atrial myxoma. Diagnostic significance of the "Systolic tumor sound" in a case presenting as tricuspid insufficiency. Amer Heart J, 78: 245, 1969.

16) Hashiba, $K$, et al: Apexcardiogram and phonocardiogram in the diagnosis of left atrial myxoma. Jap Heart J, 11: 202, 1970. -17) Nasser, WK, et al: Atrial myxoma. II. Phonocardiographic, echocardiographic, hemodynamic, and angiographic features in nine cases. Amer Heart J, 83: 810, 1972. -18) Schattendberg, TT: Echocardiografic diagnosis of left atrial myxoma. Mayo Clin Proc, 43: 620, 1968. -19) Finegan, RE and Harrison, DC: Diagnosis of left atrial myxoma by echocardiography. New Engl J Med, 282: 1022, 1970. -20) Kerber, $\mathrm{RE}$, et al: Left atrial myxoma. Demonstration by stop-action cardiac ultrasonography. Amer J Cardiol, 34: 838, 1974. 